\title{
The construction of scientific knowledge in Food and Nutrition: Analysis of dissertations and theses in the Brazilian post-graduation programs in Nutrition
}

\section{A construção do conhecimento científico em}

\author{
Alimentação e Nutrição: análise das \\ dissertações e teses nos programas de \\ pós-graduação em Nutrição brasileiros
}

Francisco de Assis Guedes de VASCONCELOS'

A B S TR A C T

\section{Objective}

To analyze dissertations and theses produced by graduate programs in nutrition in Brazil from 2003 to 2012. We sought to identify: a) The number of studies produced per year b) the scientific approach (quantitative, qualitative, or mixed), and c) the area of knowledge in the scientific field of nutrition.

\section{Methods}

This is a descriptive study. We investigated seven graduate programs linked to the area of nutrition of the Coordination for the Improvement of Higher Education Personnel, which had the web pages listing the studies. The analysis procedures included reading the titles, identifying the advisor's lines of research, reading the summaries, and reading the methods section.

\section{Results}

In the study period 758 dissertations and 204 theses were defended, signifying an increase of $229.0 \%$ for the all programs. The hegemony of the quantitative approach shows the influence of the philosophical trends linked to positivism and the biological sciences, attracting interest from $92.5 \%$ of researchers. The qualitative and mixed approaches contributed only to $7.3 \%$ of the studies, expressing the influence of the social sciences and humanities and of the philosophical trends' dialectics and phenomenology about a small group of researchers.

1 Universidade Federal de Santa Catarina, Centro de Ciências da Saúde, Departamento de Nutrição. Campus Universitário, Trindade, 88040-900, Florianópolis, SC, Brasil. E-mail: <f.vasconcelos@ufsc.br>. 


\section{Conclusion}

The distribution of dissertations and theses in the six areas of knowledge reaffirms the complexity, breadth, epistemological, and methodological heterogeneity; and the configuration of the field of knowledge production in food and nutrition, requiring the construction of collective political projects, seeking the interdisciplinarity of the different areas that structure the field.

Keywords: Education, higher. Knowledge. Nutritional Sciences.

\section{RE S U M O}

\section{Objetivo}

O presente estudo tem por objetivo analisar as dissertações e teses produzidas nos programas de pós-graduação em Nutrição no Brasil, no período de 2003 a 2012. Procurou-se identificar: (a) o número de trabalhos produzidos por ano; (b) o tipo de abordagem do conhecimento científico (quantitativa, qualitativa ou mista); e (c) os núcleos de conhecimento do campo científico da Nutrição.

\section{Métodos}

Trata-se de estudo descritivo. Foram investigados sete programas de pós-graduação vinculados à área de Nutrição da Coordenação de Aperfeiçoamento de Pessoal de Nível Superior, os quais dispunham de páginas eletrônicas contendo a relação dos trabalhos. Na análise foram realizados procedimentos de leitura dos títulos; identificação das linhas de pesquisas do orientador; leitura dos resumos; e leitura do capítulo metodológico.

\section{Resultados}

No período investigado foram defendidas 758 dissertações e 204 teses, significando um aumento de 229,0\% para o conjunto de programas. A hegemonia da abordagem quantitativa denota a influência das tendências filosóficas ligadas ao Positivismo e às Ciências Biológicas, atraindo o interesse de 92,5\% dos pesquisadores. As abordagens qualitativas e mistas contribuíram com apenas 7,3\% dos estudos, expressando a influência das Ciências Sociais e Humanas e das correntes filosóficas (dialética e fenomenologia) sobre um grupo restrito de pesquisadores.

\section{Conclusão}

A distribuição das dissertações e teses nos seis núcleos de conhecimento reafirma a complexidade, amplitude e heterogeneidade metodológica e epistemológica da conformação do campo de produção de conhecimento em Alimentação e Nutrição, exigindo a construção coletiva de projetos políticos que busquem a interdisciplinaridade dos diferentes núcleos que estruturam o campo.

Palavras-chave: Ensino superior. Conhecimento. Ciências da Nutrição.

\section{NTRODUCTION}

In the last ten years, the scientific field of Food and Nutrition in Brazil has been object of study of some investigations, which, based on distinct analytical perspectives, has attempted to approach epistemological aspects (autonomy, authority, contours, philosophical currents, domains, scientific statute, historicity, legitimacy, limits, political project, protagonists and institutions involved, and tensions and confluences, among others) of their constitution and consolidation process indicative of their heterogeneous and multidisciplinary nature ${ }^{1-6}$.
In the last seven years, graduate programs in nutrition in Brazil were also object of study of some scientific publications ${ }^{7-10}$, which, based on distinct methodological focuses, have tried to describe and analyze the profile of the existing graduate programs, founded on distinct indicators and parameters, especially those that compose the Assessment System of the Graduate Programs of the Coordenação de Aperfeiçoamento de Pessoal de Nivel Superior (Capes, Coordination for the Improvement of Higher Education Personnel).

In its historicity, academic graduate programs (known as stricto sensu in Brazil) in 
nutrition emerged from the creation of the master's program in nutrition of the Universidade Federal de Pernambuco (UFPE), launched in the first semester of $1971^{11}$. According to Kac et al. ${ }^{7}$, the academic graduate programs that composed Capes' subarea of nutrition expanded expressively in the last decade: they increased from five in 1995 to eighteen in 2011. According to Capes, in September 17, 2014, 25 programs and 36 graduate programs were linked to the assessment area of nutrition; of these, 22 were academic master's programs, 11 were academic doctorate programs, and 3 were professional master's programs $^{12}$.

Excluding the relevance, opportunity, currentness, pertinence, and political role of earlier studies $^{7-10}$ that tried to map the process of educating human resources and producing and spreading scientific knowledge in the graduate programs in nutrition in Brazil as a function of the fertility and complexity of the subject, the number of studies available is very small, indicating a gap that needs filling.

The objective of this article was to analyze the dissertations and theses produced by the graduate programs in nutrition in Brazil from 2003 to 2012.

\section{METHODS}

The following selection criteria were preestablished to identify the pertinent programs: 1) of a universe of 22 graduate and undergraduate programs linked to Capes' area of nutrition on May 15, 2013, only the programs containing academic master's and doctorate programs should be included $(n=9) ; 2)$ the programs should be described in electronic pages with a list of the defended dissertations and theses; 3) the study period would corresponded to the last 10 years (from January 2003 to December 2012).

Three programs were excluded because they did not list the defended dissertations and theses (Universidade de Brasilia [UnB]; Universi- dade Estadual de Campinas [Unicamp]; and Universidade de São Paulo [USP]). The graduate Program in Food, Nutrition, and Health of the Universidade Federal da Bahia (UFBA) was deliberately included because of its production in the field of qualitative research. Seven graduate programs in Nutrition were investigated: UFPE, Universidade Federal Rio de Janeiro (UFRJ), Universidade Federal de São Paulo (Unifesp), Universidade Federal de Viçosa (UFV), Universidade Federal de Santa Catarina (UFSC), Universidade Federal da Bahia, and Universidade do Estado do Rio de Janeiro (UERJ).

Access to the list of dissertations and theses was based on visiting the homepages of the seven programs from May 15 to May 31, 2013. Only four programs (UERJ, UFBA, UFRJ, and UFSC) provided in their electronic pages links or other resources to access the abstracts and/or full texts, in addition to the lists by year of defense. The other three programs (UFPE, UFV, and Unifesp) only listed the papers by year of defense, so we visited Capes' bank of theses to access to the abstracts.

The list of dissertations and theses of each of the seven programs was imported to a Microsoft Excel ${ }^{\circledR}$ spreadsheet where the available information, such as order number, study author, title, year of defense, name of the advisor, examiners, level, research line, area of concentration, and keywords were reorganized according to the specific interests of the present investigation.

Each dissertation or thesis was submitted to two categorization modalities: 1 ) regarding the scientific approach; and 2) regarding the core areas within the field of Nutrition.

Regarding the scientific approaches, the dissertations and theses were categorized in three modalities: quantitative approaches, qualitative approaches, and quantitative and qualitative approaches, or mixed. This categorization was based on studies of authors linked to the discipline scientific methodology, such as Creswell ${ }^{13}$. For Creswell ${ }^{13}$, the quantitative approach aims to test 
objective (deductive) theories, examine the relationship between variables that can be measured by instruments, and analyze the numerical data obtained from statistical procedures; the qualitative approach aims to explore or analyze profoundly and inductively, the meanings that an individual or groups of individuals attribute to a social or human problem; the mixed approach in turn aims to involve the simultaneous use of the quantitative and qualitative approaches, trying to potentiate the general force or the explicative power of the study in relation to the isolated use of these two approaches.

Regarding the knowledge cores of the field of Nutrition, the dissertations and theses were categorized into six modalities: a) Clinical Nutrition; b) Basic and Experimental Nutrition; c) Food Science and Technology Applied to Health; d) Nutrition in Public Health; e) Social Sciences and Humanities in Food and Nutrition; and f) Nutrition in Meal Production. This categorization was constructed based on the requirements of Capes' assessment area in Nutrition ${ }^{14}$ and the compilation done in 2009 by the "National Forum of Coordinators of Graduate Programs in Food and Nutrition" of the knowledge cores present in the graduate programs in the field of Food and Nutrition?. Hence, in the knowledge core of Clinical Nutrition, we included the dissertations and theses focused on the study of nutritional diagnoses and/or therapies of human diseases at the individual level. In the knowledge core of Basic and Experimental Nutrition, we included the dissertations and theses involving basic experimental and laboratory studies with animals and/or human beings in the fields of Biochemistry, Dietetics, Physiology, Genetics, and Pathology, among others. In the knowledge core Food Science and Technology Applied to Health, we included the dissertations and theses involving chemical composition, sanitary quality, and food engineering and technology. In the knowledge core Nutrition in Public Health, we included dissertations and theses about population nutritional diagnoses and interventions involving disciplines and contents, such as nutritional epidemiology, planning and management in food and nutrition, and policies, among others. In the knowledge core Social Sciences and Humanities in Food and Nutrition, we included the dissertations and theses with anthropological, communication-related, legal, economic, educational, philosophical, historic, geographic, and sociologic approaches, among others. In the knowledge core of nutrition in meal production, we included the dissertations and theses about meal production and consumption, and about the assessment and proposition of quality systems (nutritional, sensory, sanitary, regulatory, symbolic, and sustainable) in institutional and private food services ${ }^{7,14}$.

In the analysis for categorization of the dissertations and theses regarding the scientific approaches and the distinct knowledge cores of the scientific field of Nutrition, the following procedures were performed: 1) title reading; 2) identification of the advisor's research lines; 3 ) abstract reading; and 4) reading of the methods section/chapter.

Therefore, this is a descriptive study whose general results are presented in the form of absolute and relative frequency distribution. For some indicators, we identified the mean, standard deviation, and variation/amplitude deviation (smaller and greater).

\section{RESULTS AND DISCUSSION}

\section{Expansion of the number of dissertations and theses from 2003 to 2012}

Table 1 shows that, for the seven study programs, 962 dissertations and theses were defended from 2003 to 2012, representing an increase of $229.0 \%$ during the period. The number of studies per program also increased during the period, except at UFV, which had a smaller number of defenses in 2012 than in 2003, the year the defenses began. Of the 962 defenses, 
Table 1. Distribution of the dissertations and theses defended in the seven study graduate programs in Nutrition by year of defense for the period 2003-2012.

\begin{tabular}{|c|c|c|c|c|c|c|c|c|c|}
\hline \multirow{2}{*}{ Year of defense } & & \multicolumn{8}{|c|}{ Graduate program in Nutrition } \\
\hline & & UFPE & UFRJ & Unifesp & UFV & UFSC & UFBA & UERJ & Total \\
\hline \multirow[t]{2}{*}{2003} & $\mathrm{~N}$ & 24 & 6 & - & 14 & 4 & - & - & 48 \\
\hline & $\%$ & $(8.1)$ & (3.7) & & (9.3) & (3.3) & & & $(5,0)$ \\
\hline \multirow[t]{2}{*}{2004} & $\mathrm{~N}$ & 45 & 9 & 17 & $15(10.0)$ & 4 & - & - & 90 \\
\hline & $\%$ & $(15.2)$ & (5.5) & (16.3) & & (3.3) & & & $(5,0)$ \\
\hline \multirow[t]{2}{*}{2005} & $\mathrm{~N}$ & 25 & 14 & 15 & 14 & 5 & - & - & 73 \\
\hline & $\%$ & (8.4) & (8.6) & $(14.4)$ & (9.3) & $(4.1)$ & & & $(7,6)$ \\
\hline \multirow[t]{2}{*}{2006} & $\mathrm{~N}$ & 26 & 10 & 17 & 15 & 14 & - & - & 82 \\
\hline & $\%$ & (8.8) & (6.1) & $(16.3)$ & $(10.0)$ & (11.6) & & & $(8,5)$ \\
\hline \multirow[t]{2}{*}{2007} & $\mathrm{~N}$ & 27 & 18 & 15 & 17 & 22 & 13 & - & 112 \\
\hline & $\%$ & (9.1) & $(11.0)$ & (14.4) & (11.3) & (18.2) & $(16.1)$ & & $(11,6)$ \\
\hline \multirow[t]{2}{*}{2008} & $\mathrm{~N}$ & 30 & 29 & 21 & 17 & 12 & 10 & - & 119 \\
\hline & $\%$ & $(10.1)$ & (17.8) & $(20.2)$ & (11.3) & (9.9) & $(12.3)$ & & $(12,4)$ \\
\hline \multirow[t]{2}{*}{2009} & $N$ & 25 & 17 & 19 & 17 & 7 & 9 & 8 & 102 \\
\hline & $\%$ & (8.4) & $(10.4)$ & $(18.3)$ & (11.3) & (5.8) & $(11.1)$ & (17.4) & $(10,6)$ \\
\hline \multirow[t]{2}{*}{2010} & $N$ & 22 & 23 & - & 14 & 19 & 16 & 5 & 99 \\
\hline & $\%$ & (7.4) & $(14.1)$ & & (9.3) & (15.7) & $(19.8)$ & $(10.9)$ & $(10,3)$ \\
\hline \multirow[t]{2}{*}{2011} & $\mathrm{~N}$ & 40 & 18 & - & 19 & 14 & 18 & 18 & 127 \\
\hline & $\%$ & $(13.5)$ & (11.0) & & (12.7) & (11.6) & $(22.2)$ & (39.1) & $(13,2)$ \\
\hline \multirow[t]{2}{*}{2012} & $N$ & 33 & 19 & - & 8 & 20 & 15 & 15 & 110 \\
\hline & $\%$ & $(11.1)$ & (11.7) & & (5.3) & (16.5) & (18.5) & (32.6) & $(11,4)$ \\
\hline \multirow[t]{2}{*}{ Total } & $\mathrm{N}$ & 297 & 163 & 104 & 150 & 121 & 81 & 46 & 962 \\
\hline & $\%$ & (100.0) & $(100.0)$ & $(100.0)$ & $(100.0)$ & (100.0) & $(100.0)$ & $(100.0)$ & $(100,0)$ \\
\hline Mean & & 29,7 & 16.3 & 17.3 & 15 & 12.1 & 13.5 & 11.5 & 96.2 \\
\hline $\begin{array}{l}\text { (Standard } \\
\text { deviation) }\end{array}$ & & $(6,4)$ & (9.2) & (1.4) & (4.2) & (11.3) & (1.4) & (4.9) & (43.8) \\
\hline
\end{tabular}

Note: UFPE: Universidade Federal de Pernambuco; UFRJ: Universidade Federal do Rio de Janeiro; Unifesp: Universidade Federal de São Paulo; UFV: Universidade Federal de Viçosa; UFSC: Universidade Federal de Santa Catarina; UFBA: Universidade Federal da Bahia; UERJ: Universidade do Estado do Rio de Janeiro.

$204(21.2 \%)$ were doctoral theses (data not tabulated).

From 2003 to 2012, UFPE produced the highest number of dissertations and theses. A total of 297 dissertations and theses were defended in the study period, an annual mean of approximately 30 works, varying from 22 to 45 works/year (Table 1). UFPE's master's program in nutrition began in the first semester of $1971^{11}$ and the doctorate program was created in 19917 .

Universidade Federal do Rio de Janeiro: Graduate Program in Nutrition was the second program with the highest number of defended dissertations and theses. A total of 163 dissertations and theses were defended, an annual mean of approximately 16 works, varying from 6 to 29 dissertations per year (Table 1). UFRJ's master's program in human nutrition and doctorate program in Nutritional Sciences were created in 1985 and 2005, respectively?.

Universidade Federal de Viçosa: Programa de Pós-Graduação em Ciências da Nutrição (PPGCN, Graduate Program in the Science of Nutrition) was the third program with the highest number of defended works. A total of 150 works were defended, an annual mean of 15 works, 
varying from 8 to 19 works per year (Table 1). The master's PPGCN program was launched in 2001 and the doctorate, in March 20107.

Universidade Federal de Santa Catarina: Graduate Program in Nutrition was the fourth program with the highest volume of defended works. A total of 121 dissertations were defended, an annual mean of approximately 12 works, varying from 4 to 22 dissertations per year (Table 1). UFSC PPGN's master's program was launched in March 2002, and the doctorate, in March $2012^{7}$.

Universidade Federal de São Paulo: Graduate Program in Nutrition was the fifth program in number of defended works. Data were available only for the period from 2004 to 2009. In this period 104 dissertations and theses were defended, an annual mean of approximately 17 works, varying from 15 to 25 dissertations and theses/year (Table 1). Unifesp's master's and doctorate programs were created in 1991, under Capes' recommendation?

Universidade Federal da Bahia: Graduate Program in Food, Hutrition, and Health was the sixth program with the highest number of defended works. A total of 81 dissertations were defended, an annual mean of approximately 14 works, varying from 9 to 18 dissertations per year (Table 1). UFBA's master's program was created in March $2005^{7}$.

Universidade do Estado do Rio de Janeiro: Graduate Program in Food, Nutrition, and Health was the seventh program with the highest number of defended works. A total of 46 dissertations were defended, an annual mean of approximately 12 works, varying from 5 to 18 dissertations per year (Table 1). The master's course began in June 2007, and the doctorate course in November of 2009 following Capes' recommendation? ${ }^{7}$.

Analyzing the profile of the existing programs based on distinct Capes' assessment indicators and parameters showed that earlier publications about Brazilian graduate programs in nutrition ${ }^{7-10}$ had already identified the historic context of its emergence in the 1970's, its shy consolidation until the end of the 1990's, and its growth from 2000. Of these earlier publications, only two ${ }^{8,10}$ provide an interface for the discussion of our findings regarding the growth in the number of dissertations and theses. Taking into account the data in Capes' assessment records of only eight graduate programs in Nutrition, $\mathrm{Kac}$ et al. ${ }^{10}$ found that in the years of 2002, 2003, and 2004, the total numbers of students receiving a title (dissertations and theses) were 35,83 , and 83 , respectively; of the total $(n=201), 72(35.8 \%)$ were doctorate degrees. On the other hand, by analyzing distinct indicators of Capes' assessment system for 2007 to 2009, Olinto et al. ${ }^{8}$ found that the number of graduate programs in Nutrition grew from 10 in 2007 to 15 in 2009, and that the total number of fully educated advisees fell from 217 to 202 in the same period. Therefore, of the 632 fully educated advisees produced during those three years, 98 (15.5\%) were doctorates.

When compared with the other areas of the greater area of Health Sciences, such as Public Health and Physical Education, areas that also emerged in the 1970's, the number of graduate programs in Nutrition increased similarly to that of Physical Education, but very differently from that of collective health (an area in Brazil that branched from public health). According to Rosa \& Leta ${ }^{15}$, the first master's and doctorate programs in Physical Education in Brazil were created in 1977 and 1988, respectively, by USP; by 1995, there were ten graduate programs in Physical Education in the country; by 2009, there were 29 programs, characterizing an increase of $290 \%$ in 13 years. According to Nunes et al. ${ }^{16}$, the first Graduate Program in Public Health was created in 1970 by USP School of Public Health. According to Barata ${ }^{17}$, from 1998 to 2008, the increase in the number of accredited programs in Collective Health was higher than those of all other areas of knowledge combined. At the time (2008), according to Nunes et $a / .{ }^{16}$ and Barata ${ }^{17}$, there were 47 graduate programs in Collective Health in the country. 


\section{Hegemony of quantitative graduate research in Nutrition}

Table 2 shows that for the set of 962 dissertations and theses defended in the study programs, there is hegemony of the quantitative approach; this study approach is used by $92.5 \%$ ( $n=980)$ of the researchers. In numeric terms, the qualitative approach had a marginal participation since it was used by only $5.4 \%(n=52)$ of the researchers. The mixed approaches were used by only $1.9 \%(n=18)$ of the researchers.

When the seven programs are analyzed individually, the hegemony profile of the quantitative research was seen in every one of them, and were almost exclusive to the programs of Unifesp (99.0\%, $\mathrm{n}=103)$, UFPE $(97.4 \%$, $n=289)$, UFV (96.7\%, $n=145)$, and UFRJ (95.1\%, $n=155)$. The participation of the qualitative and mixed approaches happened more frequently in the programs of UFBA $(n=20 ; 24.7 \%)$, UERJ ( $n=13$; $28.3 \%)$, and UFSC ( $n=17 ; 14.0 \%)$. In the four other programs, the participation of the qualitative and mixed approaches was very small: $3.6 \%(n=6)$ at UFRJ, 3.3\% $(n=5)$ at UFV, $2.6 \%(n=8)$ at UFPE, and $1.0 \%(n=1)$ at Unifesp (Table 2).

These results show hegemony (in the sense proposed by Gramsci) ${ }^{18}$ of the quantitative approach in relation to the qualitative and mixed approaches. They denote the influence of philosophical currents based on positivism and biological sciences ${ }^{19-20}$ in the composition of the scientific field of Nutrition, catching the interest of $92.5 \%$ of its researchers. The participation of the qualitative and mixed approaches, attracting only $7.3 \%$ of the researchers of the field, is marginal and counter-hegemonic. It expresses the influence that the Social Sciences and Humanities and Philosophical Currents, such as dialectics and phenomenology ${ }^{19-20}$, have played on a very restrict group of researchers that compose the scientific field of nutrition. Hegemony of the paradigm (in the sense proposed by Kuhn ${ }^{21}$ ) positivistic and biological and the counter-hegemony of the paradigm centered on the social sciences and humanities and in the philosophical currents of dialectics and phenomenology have also been identified in the other scientific fields related to life sciences, such as Medicine ${ }^{22}$, Dentistry ${ }^{23}$, Nursing ${ }^{24}$, and Physical Education ${ }^{15}$, among others.

The results also show that what draws the most attention from the researchers of the graduate programs of UFBA, UERJ, and UFSC for the qualitative approach can be associated with

Table 2. Distribution of the dissertations and theses defended in the period 2003-2012 in the seven study graduate programs in nutrition by scientific knowledge approach.

\begin{tabular}{|c|c|c|c|c|c|c|c|c|c|c|}
\hline \multirow{3}{*}{$\begin{array}{l}\text { Graduate } \\
\text { program in } \\
\text { Nutrition }\end{array}$} & \multicolumn{10}{|c|}{ Type of approach of the scientific knowledge } \\
\hline & \multicolumn{2}{|c|}{ Quantitative } & \multicolumn{2}{|c|}{ Quanlitative } & \multicolumn{2}{|c|}{ Mixed } & \multicolumn{2}{|c|}{ Other } & \multicolumn{2}{|c|}{ Other } \\
\hline & $\mathrm{N}$ & $\%$ & $\mathrm{~N}$ & $\%$ & $\mathrm{~N}$ & $\%$ & $\mathrm{~N}$ & $\%$ & $N$ & $\%$ \\
\hline UFPE & 289 & 97.4 & 4 & 1.3 & 4 & 1.3 & - & & 297 & 100.0 \\
\hline UFRJ & 155 & 95.1 & 3 & 1.8 & 3 & 1.8 & 2 & $1.3^{*}$ & 163 & 100.0 \\
\hline Unifesp & 103 & 99.0 & 1 & 1.0 & - & & - & & 104 & 100.0 \\
\hline UFV & 145 & 96.7 & - & & 5 & 3.3 & - & & 150 & 100.0 \\
\hline UFSC & 104 & 86.0 & 14 & 11.6 & 3 & 2.5 & - & & 121 & 100.0 \\
\hline UFBA & 61 & 75.3 & 18 & 22.2 & 2 & 2.5 & - & & 81 & 100.0 \\
\hline UERJ & 33 & 71.7 & 12 & 26.1 & 1 & 2.2 & - & & 46 & 100.0 \\
\hline Total & 890 & 92.5 & 52 & 5.4 & 18 & 1.9 & 2 & 0.2 & 962 & 100.0 \\
\hline
\end{tabular}

Note: *Regards the development of teaching material about food and nutrition education, which do not fit into the preestablished scientific knowledge approach.

UFPE: Universidade Federal de Pernambuco; UFRJ: Universidade Federal do Rio de Janeiro; Unifesp: Universidade Federal de São Paulo; UFV: Universidade Federal de Viçosa; UFSC: Universidade Federal de Santa Catarina; UFBA: Universidade Federal da Bahia; UERJ: Universidade do Estado do Rio de Janeiro. 
the greater recency of these programs. For the other programs (excluding UFV's, which is also recent), what draws the most attention by the dominant paradigm can be associated with the institutional tradition or the institutional scientific habitus (in the sense proposed by Bourdieu) ${ }^{25}$. Therefore, the current objective and subjective conditions that determine the composition of the scientific field of Food and Nutrition in Brazil need to be identified by determining which elements motivate dieticians when they align themselves with the dominant or the alternative paradigm. Although this task is essential, it has yet to be tackled. The methodological limitations inherent to the analyzed historic period (2003 to 2012), the missing data from Unifesp's PPGN history, and the recency of UFBA's and UERJ's programs could have influenced the results, suggesting caution in the analyses and conclusions.

\section{The knowledge cores of the scientific field of nutrition: Methodological heterogeneity and knowledge multidisciplinarity}

Table 3 shows that for the 962 dissertations and theses defended in the study programs, there's a greater concentration of studies in the cores Nutrition in Public Health $(n=317 ; 33.0 \%)$ and Clinical Nutrition ( $n=289 ; 30.0 \%)$, which are followed by Basic and Experimental Nutrition $(n=147 ; 15.3 \%)$ and Food Science and Technology $(n=132 ; 13.7 \%)$. These four nuclei add up to 887 (92.0\%) defended dissertations and theses.

Nutrition in Collective Health constituted the most researched knowledge core in UFRJ $(43.6 \%)$, UFPE (33.0\%), and UFBA (29.6\%); and the second most researched in UERJ (32.6\%), UFSC (31.4\%), UFV (28.0\%), and Unifesp (27.8\%) (Table 3).

Clinical Nutrition constituted the most researched knowledge core in Unifesp (50.0\%), UFV (46.0\%), UERJ (41.3\%), and UFSC (32.2\%); the second most researched in UFRJ $(27.6 \%)$ and UFBA (29.6\%); and the fourth most researched in UFPE (15.5\%) (Table 3).

Basic and Experimental Nutrition constituted the third knowledge core most researched in UFPE (24.6\%), Unifesp (19.2\%), and UFV (12.7\%); the fourth most researched in UFSC $(10.7 \%)$, UFRJ (9.2\%), and UERJ $(2.2 \%)$; and the sixth most researched in UFBA (7.4\%) (Table 3).

Food Science and Technology was the second most researched knowledge core in UFPE $(26.6 \%)$; the third most researched in UFRJ (19.0\%); the fourth most researched in UFV (9.3); the fifth most researched in UFBA (8.6\%) and Unifesp (1.0\%); and was not researched in UFSC or UERJ (Table 3).

Table 3. Distribution of the dissertations and theses defended in the period 2003-2012 in the seven study graduate programs in Nutrition by knowledge cores of the scientific field of Nutrition.

\begin{tabular}{|c|c|c|c|c|c|c|c|c|c|c|c|c|c|c|c|c|}
\hline \multirow{3}{*}{$\begin{array}{l}\text { Knowledge cores of the scientific } \\
\text { field of Nutrition }\end{array}$} & \multicolumn{16}{|c|}{ Graduate program in Nutrition } \\
\hline & \multicolumn{2}{|c|}{ UFPE } & \multicolumn{2}{|c|}{ UFRJ } & \multicolumn{2}{|c|}{ Unifesp } & \multicolumn{2}{|c|}{ UFV } & \multicolumn{2}{|c|}{ UFSC } & \multicolumn{2}{|c|}{ UFBA } & \multicolumn{2}{|c|}{ UERJ } & \multicolumn{2}{|c|}{ Total } \\
\hline & $\mathrm{N}$ & $\%$ & $N$ & $\%$ & $N$ & $\%$ & $\mathrm{~N}$ & $\%$ & $\mathrm{~N}$ & $\%$ & $\mathrm{~N}$ & $\%$ & $N$ & $\%$ & $\mathrm{~N}$ & $\%$ \\
\hline Clinical Nutrition & 46 & 15.5 & 45 & 27.6 & 52 & 50.0 & 69 & 46.0 & 39 & 32.2 & 19 & 23.5 & 19 & 41.3 & 289 & 30.0 \\
\hline Basic and Experimental Nutrition & 73 & 24.6 & 15 & 9.2 & 20 & 19.2 & 19 & 12.7 & 13 & 10.7 & 6 & 7.4 & 1 & 2.2 & 147 & 15.3 \\
\hline Food Science and Technology & 79 & 26.6 & 31 & 19.0 & 1 & 1.0 & 14 & 9.3 & - & & 7 & 8.6 & - & - & 132 & 13.7 \\
\hline Nutrition in Collective Health & 98 & 33.0 & 71 & 43.6 & 29 & 27.8 & 42 & 28.0 & 38 & 31.4 & 24 & 29.6 & 15 & 32.6 & 317 & 33.0 \\
\hline Social Sciences and Humanities & - & - & - & - & - & - & - & - & 2 & 1.7 & 16 & 19.8 & 11 & 23.9 & 29 & 3.0 \\
\hline Nutrition in Meal Production & 1 & 0.3 & 1 & 0.6 & 2 & 2.0 & 6 & 4.0 & 29 & 24.0 & 9 & 11.1 & - & - & 48 & 5.0 \\
\hline Total & 297 & 100.0 & 163 & 100.0 & 104 & 100.0 & 1501 & 100.0 & 121 & 100.0 & 81 & 100.0 & 46 & 100.0 & 962 & 100.0 \\
\hline
\end{tabular}

Note: UFPE: Universidade Federal de Pernambuco; UFRJ: Universidade Federal do Rio de Janeiro; Unifesp: Universidade Federal de São Paulo; UFV: Universidade Federal de Viçosa; UFSC: Universidade Federal de Santa Catarina; UFBA: Universidade Federal da Bahia; UERJ: Universidade do Estado do Rio de Janeiro. 
Social Sciences and Humanities of Food and Nutrition was the third most researched knowledge core in UERJ (23.9\%) and UFBA $(19.8 \%)$ and the fifth most researched knowledge core in UFSC (1.7\%). It was not researched in UFPE, UFRJ, Unifesp, and UFV (Table 3).

Nutrition in meal production was the third most researched core in UFSC $(24.0 \%)$, fourth in UFBA $(11.1 \%)$ and Unifesp (2.0\%), fifth in UFV $(4.0 \%)$, UFRJ $(0.6 \%)$, and UFPE $(0.3)$, and was not researched by UERJ (Table 3 ).

The categorization of the dissertations and theses into the six knowledge cores of the field of Food and Nutrition allows multiple analyses and interpretations. One of the first involves the similarity between the absolute values and percentages of the dissertations and theses categorized as being quantitative ( $n=890,92.5 \%$ ) and those that compose the four "stronger" knowledge cores (Nutrition in Collective Health + Clinical Nutrition + Basic and Experimental Nutrition + Food Science and Technology) ( $n=885$, $92.0 \%)$; and between those categorized as qualitative or mixed $(n=70,7.3 \%)$ and those that compose the two "weaker' knowledge cores (Social Sciences and Humanities in Food and Nutrition + Nutrition in Meal Production) ( $n=77$, $8.0 \%)$. Generally, these results show that the researchers of the four "stronger" knowledge cores are those affiliated with the dominant paradigm, while those of the two "weaker" knowledge cores are attracted by the "alternative" paradigm.

A second aspect that can be pointed out regards a possible specific "vocation" (institutional habitus in the sense proposed by Bourdieu ${ }^{25}$ ) of each of the seven study programs and their focus on certain knowledge core(s). Thus, we can risk stating that: 1) at UFPE, although Nutrition in Collective Health had a higher frequency (33\%), the "institutional vocation" consisted of studies in the cores Food Science and Technology, and Basic and Experimental Nutrition, which constitute $51.2 \%$ of the total defended works; 2 ) at UFRJ, the "institutional vocation" consisted of Nutrition in Health, which together with Clinical Nutrition, composed $71.2 \%$ of the defended works; 3 ) at Unifesp, the "institutional vocation" consisted of Clinical Nutrition, which together with Basic and Experimental Nutrition, composed $69.2 \%$ of the defended works; 4) at UFV, the "institutional vocation" consisted of Clinical Nutrition, which together with Basic and Experimental Nutrition, composed $58.0 \%$ of the defended works; 5) at UFSC, although Nutrition in Collective Health together with Clinical Nutrition had a frequency of $63.3 \%$, the "institutional vocation" seems to consist of Nutrition in Meal Production, a knowledge core that differentiates UFSC from the other programs; 6) at UFBA, although Nutrition in Collective Health together with Clinical Nutrition had a frequency of $53.1 \%$, the "institutional vocation" seems to consist of the Social Sciences and Humanities in Food and Nutrition; and 7) at UERJ, although Clinical Nutrition together with Nutrition in Collective Health had a frequency of $73.9 \%$, the "institutional vocation" seems to consist of Social Sciences and Humanities in Food and Nutrition.

Kac et al. ${ }^{7}$ reviewed thirteen graduate programs in Nutrition from Capes' 2009 Indicator Notebooks and found 69 research lines in the following distribution of the six knowledge cores in decreasing order: 1) Nutrition in Collective Health, involving nutritional epidemiology and food and nutrition policies ( $n=23,33.0 \%) ; 2$ ) Basic and Experimental Nutrition ( $n=14,20.3 \%)$; 3) Food Science and Technology $(n=11,16.0 \%)$; 4) Clinical Nutrition ( $n=10,14.5 \%)$; 5) Social Sciences and Humanities in Food and Nutrition ( $n=6$, 8.7\%); and 6) Nutrition in Meal Production ( $n=5$, 7.2\%). Excluding the methodological differences, some results of the abovementioned study are similar to the present results while others are different. The present results stem from the compilation of all the dissertations and theses produced in the historic series 2003 to 2012 by only seven of the 13 programs investigated by Kac et al. ${ }^{7}$, who investigated the research lines available in the graduate programs in Nutrition 
available in 2009. Such methodological differences may explain the different order of distribution frequency found by the present study, which is as follows in decreasing order of knowledge cores: 1) Nutrition in Collective Health; 2) Clinical Nutrition; 3) Basic and Experimental Nutrition; 4) Food Science and Technology; 5) Nutrition in Meal Production; and 6) Social Sciences and Humanities in Food and Nutrition.

Lastly, as we discuss the results regarding the six knowledge cores that we attributed to the scientific field of Nutrition, we should bear in mind some recent reflections on the disciplinarity, multidisciplinarity, and methodological/epistemological heterogeneity of this field 1,3-6,26.

In their investigation of the qualitative studies in Food and Nutrition published in Brazil between 1985 and 2007, Canesqui ${ }^{26}$ argued that both the undergraduate and graduate curricula have approximated Nutrition (anchored in Biology, Physiology, and objective and material instruments and procedures) and the Social Sciences and Humanities (anchored in comprehensive, historic, and ideological approaches that imply subjectivity and intersubjectivity) in a more disciplinary than multidisciplinary fashion. Although the author identified the researchers' efforts in studies on the field of development of multidisciplinary studies, she draws attention to the need of constructing interdisciplinary projects of which the frontiers of the disciplines become permeable.

Freitas et al. ${ }^{4}$ discussed the approximation between the fields of Food and Nutrition in a hermeneutic or comprehensive manner and identified the hegemony of the biochemical paradigm and the centralization of the technical knowledge in the studies of Nutrition. These authors' approaches tend towards the belief that "the field of Food and Nutrition is necessarily interdisciplinary because it includes not only technical knowledge but also culture and all the relationships that permeate the senses and food practices" (p.32).

While discussing the concepts, domains, and political projects in the scientific field of Food and Nutrition in Brazil and the constitution, contours, and scientific statute of the knowledge core of Food and Nutrition in Collective Health, Bosi \& Prado ${ }^{3}$ and Prado et al. ${ }^{6}$ also tend towards identifying centrality and hegemony of the positivist and biological paradigm and the confluence of other paradigms in the process of constituting and consolidating this scientific field. In this sense, the authors point out the comprehensive and eminently multi-epistemic character of the field of production of knowledge in Food and Nutrition, as well as routes to construct interdisciplinarity.

In an earlier study about the transition of paradigms in the historic trajectory of Nutrition in Brazil ${ }^{1}$, we stated that the historic analysis evidenced that "in addition to the biological nature, Brazilian Nutrition assumed social and environmental dimensions from its birth, characterizing as a multidisciplinary field of knowledge consisting of the integration of Biological, Social, and Food and Nutrition Sciences". We also claimed that "in the last decades, the fast development of communication, information technology, genetics, and theories about the ecological sustainability of planet Earth have produced important paradigmatic changes in the field of Nutrition"; and that "nutrition would be living a post-genomic era, constituting a multidisciplinary science, characterized by the integration of the biological, social, and environmental dimensions" (p.935).

\section{CONCLUSION}

In conclusion, analysis of the dissertations and theses produced between 2003 and 2012 by the graduate programs in Nutrition can be summarized as follows:

1. A total of 758 dissertations and 204 theses were defended, totaling 962 works. The number of dissertations and theses increased by $229.0 \%$ in the set of study programs;

2. Universidade Federal de Pernambuco was the graduate program with the highest 
number of dissertations and theses ( $n=297)$, of which 160 (53.9\%) were dissertations and 137 $(46.1 \%)$ were theses. They produced annually roughly 14 theses and 16 dissertations;

3. In ordinal sequence by number of defended works, UFRJ's program ranked second with 163 works; UFV ranked third with 150 works; UFSC ranked fourth with 121 works; Unifesp ranked fifth with 104 works; UFBA ranked sixth with 81 works; and UERJ ranked seventh with 46 works. We emphasize the limitation of this type of comparison/ ranking because Unifesp, UFBA, and UERJ data was missing for the study period (2003 to 2012): either their program was launched after 2003 or the information was not available;

4. The hegemony of the quantitative approach in relation to the qualitative and mixed approaches denote the influence of the philosophical currents positivism and Biological Sciences in the composition of the scientific field of Nutrition, attracting the interest of $92.5 \%$ of its researchers;

5. The participation of the qualitative and mixed approaches expresses the influence that the Social Sciences and humanities and the Philosophical Currents, such as dialectics and phenomenology, have had on a very small group of researchers who work in the scientific field of Nutrition (only 7.3\%);

6. A greater number of studies focused on the following knowledge cores: Nutrition in Collective Health $(n=317 ; 33.0 \%)$ and Clinical Nutrition ( $n=289 ; 30.0 \%$ ); followed by basic and experimental nutrition ( $n=147 ; 15.3 \%)$; and finally by Food Science and Technology $(n=132$; $13.7 \%$ ). These four knowledge cores totaled 887 (92.0\%) defended dissertations and theses;

7. The knowledge cores Nutrition in Meal Production ( $n=48 ; 5.0 \%$ ) and Social Sciences and Humanities in Food and Nutrition ( $n=29 ; 3.0 \%$ ) presented an emerging production, totaling 77 $(8.0 \%)$ of the defended dissertations and theses;
8. The distribution of the dissertations and theses into six knowledge cores reaffirms the complexity, scope, and methodological and epistemological heterogeneity of the current composition of the field of knowledge production in Food and Nutrition in the graduate programs, requiring the collective construction of political projects that focus on the interdisciplinarity of the distinct knowledge cores that structure the field.

\section{REFEREN CES}

1. Vasconcelos FAG. A ciência da nutrição em trânsito: da nutrição e dietética à nutrigenômica. Rev Nutr. 2010; 23(6):935-45. http://dx.doi.org/10.1590/ S1415-52732010000600001

2. Vasconcelos FAG, Calado CLA. Profissão nutricionista: 70 anos de história no Brasil. Rev Nutr. 2011; 24(4):605-17. http://dx.doi.org/10.1590/ S1415-52732011000400009

3. Bosi MLM, Prado SD. Alimentação e nutrição em saúde coletiva: constituição, contornos e estatuto científico. Ciênc Saúde Colet. 2011; 16(1):7-17. http://dx.doi.org/10.1590/S1413-81232011000 100002

4. Freitas MCS, Minayo MCS, Fontes GAV. Sobre o campo da alimentação e nutrição na perspectiva das teorias compreensivas. Ciênc Saúde Colet. 2011; 16(1):31-8. http://dx.doi.org/10.1590/S141 3-81232011000100008

5. Vasconcelos FAG, Batista Filho M. História do campo da alimentação e nutrição em saúde coletiva no Brasil. Ciênc Saúde Colet. 2011; 16(1):81-90. http://dx.doi.org/10.1590/S1413-812320110 00100012

6. Prado SD, Bosi MLM, Carvalho MCVS, Gugelmin SA, Mattos RA, Camargo Junior KR, et al. Alimentação e nutrição como campo científico autônomo no Brasil: conceitos, domínios e projetos políticos. Rev Nutr. 2011; 24(6):927-38. http:// dx.doi.org/10.1590/S1415-52732011000600013

7. Kac G, Proença RPC, Prado SD. A criação da área "nutrição" na Capes. Rev Nutr. 2011; 24(6):905-16. http://dx.doi.org/101590/S1415-527320110006 00011

8. Olinto MTA, Lira PIC, Marchini JS, Kac G. Formação humana, pesquisa e produção científica na subárea de avaliação "nutrição" da Coordenação de Aperfeiçoamento de Pessoal de Nível Superior, no Brasil, de 2007 a 2009. Rev Nutr. 2011; 24(6):917-26. http://dx.doi.org/10.1590/S1415-5273201100060 0012 
9. Kac G, Fialho E, Santos SMC, Assis AMO. Reflexões do I Fórum de Coordenadores de Programas de Pós-Graduação em Nutrição no Brasil. Rev Nutr. 2006; 19(6):785-92. http://dx.doi.org/10.1590/S1 415-52732006000600013

10. Kac G, Fialho E, Santos SMC. Panorama atual dos programas de pós-graduação em Nutrição no Brasil. Rev Nutr. 2006; 19(6):771-84. http://dx.doi.org/ 10.1590/S1415-52732006000600012

11. Vasconcelos FAG. Um perfil de Nelson Chaves e da sua contribuição à nutrição em saúde pública no Brasil. Cad Saúde Pública. 2001; 17(6):1505-18. http://dx.doi.org/10.1590/S0102-311X200100 0600035

12. Coordenação de Aperfeiçoamento de Pessoal de Nível Superior. Relação de cursos recomendados e reconhecidos. Brasília: Capes, 2014 [acesso 2014 set 17]. Disponível em: http://conteudoweb. capes.gov.br/conteudoweb/ProjetoRelacaoCursos Servlet?acao=pesquisarAreaAvaliacao

13. Creswell JW. Projeto de pesquisa: métodos qualitativo, quantitativo e misto. $3^{\text {a }}$ ed. Porto Alegre: Artmed; 2010.

14. Coordenação de Aperfeiçoamento de Pessoal de Nível Superior. Comunicado n 002/2012: Área de Nutrição. Orientações para novos APCNS-2012. Brasília: Capes; 2014 [acesso 2014 set 17]. Disponível em: http://www.capes.gov.br/images/stories/ download/avaliacao/Criterios_APCNs_Nutricao.pdf

15. Rosa S, Leta J. Tendências atuais da pesquisa brasileira em Educação Física. Parte 2: a heterogeneidade epistemológica nos programas de pósgraduação. Rev Bras Educ Fís Esporte. 2011; 25(1):7-18. http://dx.doi.org/10.1590/S1807-55 092011000100002

16. Nunes ED, Ferreto LE, Barros NF. A pós-graduação em Saúde Coletiva no Brasil: trajetória. Ciênc Saúde Colet. 2010; 15(4):1923-34. http://dx.doi.org/ 10.1590/S1413-81232010000400008
17. Barata RB. A pós-graduação e o campo da Saúde Coletiva. Physis. 2008; 18(2):189-14. http://dx.doi. org/10.1590/S0103-73312008000200002

18. Gramsci A. Os Intelectuais e a organização da cultura. $2^{a}$ ed. Rio de Janeiro: Civilização Brasileira; 1978.

19. Minayo MCS. O desafio do conhecimento: pesquisa qualitativa em saúde. 9a ed. São Paulo: Hucitec; 2006.

20. Vasconcelos FAG. A pesquisa qualitativa nos programas de pós-graduação em nutrição no Brasil: análise das dissertações e teses. Demetra. 2013; 8(Suppl. 1):329-48. http://dx.doi.org/10.12957/ demetra.2013.6741

21. Kuhn TS. O caminho desde a estrutura. São Paulo: Unesp; 2006.

22. Tesser CD, Luz MT. Uma introdução às contribuições da epistemologia contemporânea para a Medicina. Ciênc Saúde Colet. 2002; 7(2):363-72. http://dx. doi.org/10.1590/S1413-81232002000200015

23. Gomes D, Ros MA. A etiologia da cárie no estilo de pensamento da ciência odontológica. Ciênc Saúde Colet. 2008; 1(3):1081-90. http://dx.doi.org/ 10.1590/S1413-81232008000300031

24. Rocha SMM, Silva GB. Linhas filosóficas e ideológicas na pesquisa em enfermagem no Brasil. Rev Bras Enferm. 1987; 40(4):214-21.

25. Bourdieu P. Para uma sociologia da ciência. Lisboa: Biblioteca 70; 2008.

26. Canesqui AM. Pesquisas qualitativas em nutrição e alimentação. Rev Nutr. 2009; 22(1):125-39. http:// dx.doi.org/10.1590/S1415-52732009000100012

Received: April 9, 2014

Final version: September 22, 2014 Approved: October 1, 2014 